\title{
Promoted soil C and aggregate stability in soil applied with bio-fertilizer in North China Plain
}

\author{
Li-xia Zhu ${ }^{1}$, Jutian Chen ${ }^{1}$, Fuli Zhang ${ }^{1}$, Lili Li ${ }^{1}$, and Tianxue $\operatorname{Liu}^{2}$ \\ ${ }^{1}$ Zhoukou Normal University \\ ${ }^{2}$ Henan Agricultural University
}

May 19, 2020

\begin{abstract}
Application of bio-fertilizer can improve soil fertility and retard the soil degradation. Based on a field experiment, the changes of soil organic $\mathrm{C}$, aggregate stability and organic $\mathrm{C}$ in aggregate fractions were analyzed to investigate the effects of bio-fertilizer (BF) combined with a reduced chemical fertilizer. Bio-fertilizer was applied at rates of 0 (BF0), 30 (BF30), 50 (BF50) and 70 (BF70) t ha-1 and soil samples were collected from 0-20 cm layer in 2018 and 2019. Soil cores were separated into three aggregate sizes $(>0.25 \mathrm{~mm}, 0.053-0.25 \mathrm{~mm}$ and $<0.053 \mathrm{~mm}$ ) using the wet sieving method. The highest soil organic C and water soluble organic $\mathrm{C}$ were measured in BF70, while BF50 had the highest concentrations of microbial biomass carbon, extractable organic $\mathrm{C}$ and KMnO4-C. Significant increases of mean weight diameter (3.16 mm in 2018 and $3.39 \mathrm{~mm}$ in 2019) in BF50 compared with BF0 showing the improved soil structural stability after bio-fertilizer application. Increased with increasing bio-fertilizer application rates then remained relative stable, organic $\mathrm{C}$ in aggregate fractions was highest in BF50. More organic $\mathrm{C}$ was accumulated in aggregates of $0.053-0.25 \mathrm{~mm}$ in bio-fertilizer amended soils, suggested that $\mathrm{C}$ was mainly occluded in microaggregate and benefit for protection of $\mathrm{C}$ from microbial decomposition. Our results indicated that bio-fertilizer combined with chemical fertilizer was effective in increasing organic $\mathrm{C}$ and its labile fractions, which promoted soil structural stability in turn, thereby improving soil quality.
\end{abstract}

\section{Introduction}

In cropland soil, the preservation or improvement of soil quality and productivity is of major importance. Enhancing the yield and nutritional quality of agricultural produce while maintaining the soil quality including the soil carbon level is a challenge for sustainable agriculture. Currently, intensive agriculture generally relies on synthetic fertilizer application, which leaded to considerable environmental risks and economic loess. For example, up to $50 \%$ of $\mathrm{N}$ runs off from cropland and cause greenhouse gas emission and soil degeneration (Cui et al., 2018; Ramesh et al., 2019). Additionally, soil fertility declines with continuous application of inorganic fertilizers without organic inputs due to soil acidification and degradation of soil structure (Liang et al., 2013). Therefore, development of agriculture in a low-input and suitable way is urgently needed for the transition to sustainable agriculture while reducing the trade-offs (Ramesh et al., 2019).

Soil organic C (SOC) is an important component playing key multifunctional roles in soil quality and determining many soil physical and biological properties (Lal, 2009). Various factors influence SOC content, such as regional climate, soil conditions, aggregate stability and agricultural management practices can elevate SOC content by affecting the balance between $\mathrm{C}$ input and $\mathrm{C}$ output. Fertilization has been widely used as a common management practice to increase SOC level. In general, fertilization with organic fertilizers alone or plus chemical fertilizers tend to increase SOC level (Zhang, Ding, Yu, \& He, 2015; Zhang et al., 2017), while chemical fertilizer alone yielded in inconsistent results (Bado, Lompo, Sedogo, \& Cescas, 2010; Gong, Yan, \& Wang, 2012). Fertilizer N might positively affect SOC accumulation and macro-aggregate formation due to increased residue biomass input (Tang, Xiao, Li, Wang, \& Pan, 2018), it could also decrease SOC via 
increasing SOC mineralization which primed by $\mathrm{N}$ fertilizer addition (Su, Wang, Suo, Zhang, \& Du, 2006). However, Tripathi et al. (2014) showed that no difference of soil aggregate distribution and SOC between soil received fertilizer $\mathrm{N}$ and soil not received fertilizer N. Soil organic matter can be the nucleus for aggregate formation and act as a soil binding agent, and SOC sequestration is closely associated with the stability and structure of soil aggregates (Bronick \& Lal, 2005). The aggregate-associated C and $\mathrm{N}$ are protected from mineralization because of their being less vulnerable to degradation. Additionally, stable soil aggregates can reduce soil erosion and surface runoff. Therefore, regarding the detrimental impacts of chemical fertilizer alone on soil aggregates and $\mathrm{C}$ level, a new pragmatic fertilization strategy is urgently needed.

The application of bio-fertilizers that contains living microorganisms is one of the management practices that can help to maintain or increase the content of organic matter and improve soil fertility in arable soils. More recently, it was reported that application of a chemical fertilizer mixed with bio-fertilizer, contained living microorganisms, was regarded as an efficient way to supplement soil nutrient level (Vessey, 2003), improve soil physic-chemical properties and regulate soil microbial community structure, which were benefit for crop yields (Liu et al., 2017; Singh et al., 2019). Many studies have focused on the impacts of bio-fertilizer and chemical fertilizer on soil microorganisms (Zhang, Xu, Wang, Wu, \& Xiao, 2020), such as bacterial community (Wu et al., 2016), antagonistic bacteria abundance (Li, Tao, Ling, \& Chu, 2017). Though studies have determined the effects of bio-fertilizer supplement on soil aggregate stability and organic C content (Graf \& Frei, 2013; Yilmaz \& Sönmez, 2017). However, changes of soil C fractions and soil aggregation in soil applied with bio-fertilizer and chemical fertilizer in North China Plain was not very unclear.

The North China Plain is an important food-production area in China. The major agricultural planting system in this region, summer maize (Zea mays L.)-winter wheat (Triticum aestivum L.) double cropping system, is characterized by intensive farming with high applications of mineral fertilizers (nitrogen and phosphorous) and no extra organic materials application. This resulted in high mineralization of native SOC due to increased microbial biomass and cellulose-decomposing enzymes (Kumar, Shahid, Tripathi, Mohanty, \& Nayak, 2017; Liu et al., 2017). What's more, high frequency of rotary cultivators also aggregated the decomposition of soil native organic C. Application of organic materials has been adopted by farmers to improve soil quality. It has been showed that the soil microbial abundance generally increased with biofertilizer application rates. However, whether the soil $\mathrm{C}$ and soil aggregates would show a similar tendency remains unknown. Therefore, to achieve a balance between soil conservation and economic benefits, it is necessary to adopt appropriate bio-fertilizer application rate for improving soil structure and promoting sustainable crop production.

To fill this knowledge gap, based on a field experiment under different bio-fertilizer application rates, the objectives of this study were to 1) investigate concentrations of SOC, soil labile organic C and basal respiration after two years of bio-fertilzer addition; 2) determine soil aggregate and distribution of organic $\mathrm{C}$ and $\mathrm{N}$ in different aggregates in North China Plain. The results from this study can be useful to further understand the potential of bio-fertilizer to change quality of soil organic matter under field conditions. We hypotheses that bio-fertilizer will increase SOC in soil and aggregates, and be benefit for the content of macro-aggregate and the water stable aggregate stability.

\section{Materials and methods}

\subsection{Site description}

A two-year field experiment was conducted from 2018 to 2019 in Xun County $\left(114^{\circ} 40^{\prime} \mathrm{E}, 34 \mathrm{deg} 40^{\prime} \mathrm{N} ; 72.3 \mathrm{~m}\right.$ above mean sea level), Henan Province, China. The study field is located in a warm, semi-humid region with a continental climate. The annual mean temperature in this region is 13.7 , and the frost-free period lasts 220 days. The average annual rainfall is $647.8 \mathrm{~mm}$, with above $60 \%$ of the local rainfall is concentrated in the summer, which can satisfy the water requirement for summer maize. The crop rotation in this region is winter wheat (Triticum aestivum L.) followed by summer maize (Zea mays L.) every year. The soil type is calcareous (Fluvo-Aquic soil) with $\mathrm{pH}$ of 7.88. It is a typical soil in the region with a profile of sandy loams with a texture of $65 \%$ sand, $25 \%$ silt, and $10 \%$ clay. The basic properties $(0-20 \mathrm{~cm}$ depth $)$ of soil are organic 
matter $15.0 \mathrm{~g} \mathrm{~kg}^{-1}$, total nitrogen $1.1 \mathrm{~g} \mathrm{~kg}^{-1}$, Olsen-P $30.5 \mathrm{mg} \mathrm{kg}-1$ and $\mathrm{NH}_{4} \mathrm{OAc}-\mathrm{K} 95.1 \mathrm{mg} \mathrm{kg}^{-1}$.

\subsection{Experimental design}

The field experiment was established in a randomized complete block design with three triplicates, and each plot cover an area of $40 \mathrm{~m}^{2}(5 \mathrm{mx} 8 \mathrm{~m})$. The summer maize variety was Zhengdan 958. Six treatments were (1) BF0: $100 \%$ NPK chemical fertilizer; (2) BF30 (70\% NPK chemical fertilizer $+30 \%$ bio-fertilizer); (3) BF50 (50\% NPK chemical fertilizer + 50\% bio-fertilizer); (4) BF70 (30\% NPK chemical fertilizer $+70 \%$ bio-fertilizer); (5) BF100 (100\% bio-fertilizer). All these treatments received same amounts of fertilizers (225 $\mathrm{kg} \mathrm{N} \mathrm{ha-1,} 80 \mathrm{~kg} \mathrm{P} \mathrm{ha-1}$ and $80 \mathrm{~kg} \mathrm{~K} \mathrm{ha}^{-1}$ ) during the growing season. Both the chemical fertilizer and bio-fertilizer were spread evenly on the surface of the soil in each plot and were thoroughly mixed with the top $0-20 \mathrm{~cm}$ of the soil by rotary cultivator, a week prior to maize sowing. In each plot, summer maize was planted at a density of 65000 plants ha ${ }^{-1}$ about $5 \mathrm{~cm}$ deep in early June, and harvested in early October each experimental year.

Bio-fertilizer used in this experiment was aerobically fermented from wheat straw The bio-fertilizer (organic matter $29.7 \%$, total $\mathrm{N} 12 \%$, total $\mathrm{P} 0.5 \%$, total K $5 \%$ ) contains approximately $0.2 \times 10^{9} \mathrm{CFU} \mathrm{g}^{-1}$ fungus (Trichoderma asperellum ACCC30536), the fungus were previously isolated from the rhizosphere soil of healthy soybean roots in a field severely affected byFusarium oxysporumin in Zhoukou, Henan province, China.

\subsection{Soil sampling}

Soil cores were collected from 0-20 cm layer after maize harvest in October 2018 and 2019, three replicates in each plot were drilled and then homogenized to form a constitute sample for each layer. Soil samples were sieved through an 8-mm stainless steel to remove visible materials, transported to laboratory and stored at $4 \operatorname{deg} \mathrm{C}$ in a cooler. The samples were divided into three sets of subsamples. One set was air-dried at room temperature to determine the aggregate size distribution using an aggregate analyzer; one set was used to determined soil water content and microbial biomass carbon (MBC), water soluble organic carbon (WSOC), and extractable organic carbon (EOC), as well as basal respiration (BR); and the other set was air-dried and ground to pass a $0.15 \mathrm{~mm}$ sieve for determination of $\mathrm{SOC}$ and $\mathrm{KMnO}_{4}$-oxidized organic carbon $\left(\mathrm{KMnO}_{4}-\mathrm{C}\right)$.

\subsection{Soil aggregate separation}

The wet sieving method (Elliott, 1986) was used to separate soil aggregates into three size fractions: (i) macro-aggregates $(>0.25 \mathrm{~mm})$ (ii) micro-aggregates $(0.053-0.25 \mathrm{~mm})$, (iii) silt plus clay $(<0.053 \mathrm{~mm})$. Briefly, four $50 \mathrm{~g}$, air-dried soil subsamples were placed into a $0.25 \mathrm{~mm}$ sieve and slowly immersed with $5 \mathrm{~mL}$ of deionized water for $5 \mathrm{~min}$ prior to sieving. Then, the samples were placed into a shaker consisting of two sieves $(0.25$ and $0.053 \mathrm{~mm})$ in series and vertically shaken $(3 \mathrm{~cm}) 50$ times over 5 min. After sieving, aggregates remaining in each sieve were flushed into separate beakers, and those remaining in the bucket $(<0.053 \mathrm{~mm})$ were precipitated in calcium chloride for $24 \mathrm{~h}$. The fractionated samples were dried at $60 \operatorname{degC}$ and weighed. The water stable macro-aggregate content with a diameter of $>0.25 \mathrm{~mm}$ and mean weight diameter (MWD) were calculated according to Zhang et al. (2014). A portion of each aggregate sample was ground to pass through a $0.15 \mathrm{~mm}$ sieve and used for determination of organic $\mathrm{C}$ content.

\subsection{Analysis of soil C fractions}

The soil water content was determined at $105 \operatorname{degC}$ for $24 \mathrm{~h}$ with an oven to a consistent weight. SOC in native soil and soil aggregates was determined by the chemical oxidation using $\mathrm{K}_{2} \mathrm{Cr}_{2} \mathrm{O}_{7}$ solution. $\mathrm{MBC}$ concentration was measured using a modified chloroform fumigation extraction method and calculated as difference between soluble $\mathrm{C}$ or $\mathrm{N}$ of the fumigated and non-fumigated soils (Wu, Joergensen, Pommerening, Chaussod, \& Brookes, 1990). WSOC was extracted from solutions of $20 \mathrm{~g}$ fresh soil with $40 \mathrm{ml}$ distilled water according to Liang et al. (1997). EOC was extracted from $10 \mathrm{~g}$ fresh soil with $50 \mathrm{ml} 0.5 \mathrm{M} \mathrm{K}_{2} \mathrm{SO}_{4}$ at room temperature, shaking for $1 \mathrm{~h}$ at $220 \mathrm{r} \mathrm{min}^{-1}$, filtered with a $0.45 \mu \mathrm{m}$ membrane filter (Jones \& Willett, 2006). Total organic $\mathrm{C}$ concentrations in the above filtrates were all analyzed with an automated TOC analyzer. $\mathrm{KMnO}_{4}$-C concentration was measured with $333 \mathrm{mmol} \mathrm{L}^{-1} \mathrm{KMnO}_{4}$ based on the difference 
between subsamples and the blank (only $\mathrm{KMnO}_{4}$ ) referred to Blair et al. (1995). The BR was determined with an incubation method (Carter, Kunelius, \& Angers, 1994). Briefly, $100 \mathrm{~g}$ fresh soil subsample was laid in an air tight flask of $500 \mathrm{ml}$ at $37{ }^{\circ} \mathrm{C}$, the evolved $\mathrm{CO}_{2}$ was trapped in $50 \mathrm{ml}$ of $0.2 \mathrm{M} \mathrm{NaOH}$ contained in a vial placed inside the flask. The vials were removed 1 day after initiating the incubation, and titrated with standardized $0.2 \mathrm{M} \mathrm{HCl}$ after addition of $1 \mathrm{ml}$ of $3 \mathrm{M} \mathrm{BaCl}_{2}$ using phenolphthalein as a visual indicator. Each treatment was replicated 3 times and 2 flasks without soil were used as blank control.

\subsection{Statistical analysis}

Data collected from the determination were subjected to one-way analysis of variance (ANOVA) to analyze differences in the tested parameters using SPSS 19.0 (SPSS Inc., Chicago, USA). The Duncan's Multiple Range Test (DMRT) at a $5 \%$ level of significance was used to test significance of differences between means when F-values were significant. Simple regress analysis was used to quantify the relationships among the response variables. Prior to analysis, data were tested for homogeneity of variance and normality. Figure was accomplished with SigmaPlot 12.0 (Systat Software Inc., London, UK).

\section{Results}

\subsection{Soil total organic $\mathrm{C}$ and labile $\mathrm{C}$ fractions}

The SOC significantly increased with increasing bio-fertilizer rates in both years, especially in 2018. The highest SOC was read in BF100, followed by BF70, BF50, BF30 and BF0 (Fig. 1A). BF30, BF50, BF70 and BF100 significantly increased SOC by $12.0 \%, 43.2 \%, 69.3 \%$ and $71.2 \%$ in 2018, of which no significant difference was observed between BF70 and BF100; BF30 had no significant effect on SOC but BF50, BF70 and BF100 increased it by $44.0 \%, 66.5 \%$ and $68.2 \%$ in 2019 .

Bio-fertilizer application affected four types of labile organic fractions, while had no effect on BR (Fig. 1B, $\mathrm{C}, \mathrm{D}, \mathrm{E}$ and $\mathrm{F}$ ). As to $\mathrm{MBC}$, bio-fertilizer irrespective of application rates significantly increased $\mathrm{MBC}$ in both 2018 and 2019. Of which, MBC of treatments BF50, BF70 and BF100 showed no difference, though MBC of BF50 was slight high. Bio-fertilizer had no significant effect on EOC in 2018, while variable effects were observed in 2019. EOC was significantly increased by $24.3 \%$ in BF50 and was significantly decreased by $3.2 \%$ and $2.7 \%$ in BF70 and BF100, but no difference was recorded between BF0 and BF30 in 2019. The WSOC was significantly increased by bio-fertilizer, and showed a similar tendency in 2018 and 2019. The highest WSOC was read in BF50 in both years, while there was no difference between BF30, BF70 and BF100. Bio-fertilizer significantly increased the $\mathrm{KMnO}_{4}$-C in both years, but no difference was observed among treatments applied with bio-fertilizer. The BR was generally decreased by bio-fertilizer application, with an order of BF0 $>$ BF30 $>$ BF50 $>$ BF70 $>$ BF100 in both years.

\subsection{Water stable aggregate stability}

Among the treatments, the macro-aggregates that size $>0.25 \mathrm{~mm}$ accounted for $35.4 \%$ to $55.9 \%$ of the soil weight in 2018 and $37.4 \%$ to $60.6 \%$ in 2019 (Table 1). Bio-fertilizer significantly the quantities of macroaggregate, increases in BF30, BF50 and BF70 were $22.9 \%, 57.9 \%$ and $13.3 \%$ compared with BF0 in 2018, but there was no significant difference between BF30 and BF70; BF100 had no significant effect on the content of macro-aggregate in 2018. The micro-aggregate $(0.25-2 \mathrm{~mm}$ aggregate) were significantly decreased by bio-fertilizer application. The lowest quantity of micro-aggregate was observed in BF50, which was $84.5 \%$ of BF0 in 2018. The contents of $<0.053 \mathrm{~mm}$ aggregate showed a similar tendency to micro-aggregate in 2018 , namely, the $<0.053 \mathrm{~mm}$ aggregate was significantly decreased by bio-fertilizer except for BF 100 . The lowest value was recorded in BF50, and no significant difference was observed between BF30 and BF70. In 2019, the distribution of soil aggregate showed a similar trend with that in 2018. Significant increase of macro-aggregate and decrease of $<0.053 \mathrm{~mm}$ aggregate were recorded, and the change of aggregate quantity in BF50 was the largest. BF30 significantly increased the micro-aggregate content and BF50 significantly decreased it, while BF70 had no significant effect on the micro-aggregate compared with BF0.

The values of MWD ranged from 2.16 to $3.16 \mathrm{~mm}$ in 2018 and from 2.24 to $3.39 \mathrm{~mm}$ in 2019 , respectively. Compared with BF0, BF50 significantly increased MWD by $46.1 \%$ in 2018 and by $51.2 \%$ in 2019 while BF30 
and BF70 had no effect on MWD compared with BF0 in both years. In addition, the MWD was not affected by BF100 compared with that of BF0 in both years.

\subsection{Aggregate SOC content}

Content of organic $\mathrm{C}$ in aggregate fractions were significantly affected by bio-fertilizer application and tended to increase first and then decreased with increasing bio-fertilizer rates (Table 2). The 0.053-0.25 mm fraction contained the largest content of organic $\mathrm{C}$ while $<0.053 \mathrm{~mm}$ fraction recorded the lowest. For the year 2018 , the increases in organic $\mathrm{C}$ of $>0.25 \mathrm{~mm}$ aggregate were $27.0 \%, 64.7 \%, 48.0 \%$ and $51.9 \%$ for $\mathrm{BF} 30$, BF50, BF70 and BF100, respectively $(P<0.05)$, compared with BF0. In the year 2019, BF50 and BF70 significantly increased organic $\mathrm{C}$ content of $>0.25 \mathrm{~mm}$ aggregate, while BF30 had no effect on it. The organic $\mathrm{C}$ content of $<0.053 \mathrm{~mm}$ aggregate followed the order of BF50 = BF70 = BF100 $>$ BF30 $>$ BF0 in 2018 and in 2019. Generally, the organic C content in BF50 was the highest in the three soil aggregate fractions in both years.

\subsection{Relationships among organic C fractions}

The fractions of SOC showed significant or not significant correlations between each other (Table 3). MBC, contributed to microbial activities in formation of aggregate, was positively correlated with WSOC $(\mathrm{r}=$ $0.79, P<0.01), \mathrm{KMnO}_{4}-\mathrm{C}(P<0.001)$, BR $(\mathrm{r}=-0.50, P<0.01)$ and MWD $(\mathrm{r}=0.40, P<0.05)$. The EOC was positively correlated with WSOC $(\mathrm{r}=0.44, P<0.05)$ and MWD $(\mathrm{r}=0.63, P<0.01)$. Positively correlation between WSOC and $\mathrm{KMnO}_{4}-\mathrm{C}$ was observed, and WSOC was correlated with MWD $(\mathrm{r}=0.72$, $P<0.01$ ). Additionally, the MWD was also positively correlated with $\mathrm{KMnO}_{4}$-C content.

\section{Discussions}

\subsection{Soil water aggregate distribution and stability}

Generally, the proportion of water stable macro-aggregate is an early indicator of improved aggregation, which usually boosts MWD. The addition of bio-fertilizer affected soil aggregation and improved aggregate stability in this study. The orders of effectiveness of the bio-fertilizer on the content and stability of macroaggregate were as follows: BF50 > BF30 = BF70 > BF0. This might be that the mycorrhizal development and activity have increased after application of bio-fertilizer, which enhanced aggregate stability in the end. Studies have shown that preparations of fungal origin are vital for the soil aggregate stability (Bethlenfalvay \& Barea, 1994; Yilmaz \& Sonmez, 2017). The bio-fertilizer supplement half of chemical fertilizer was found to be more effective in ensuing stability of macro-aggregate. The supplement of bio-fertilizer provided soil organic addition since it was produced from wheat straw. This organic matter brought from bio-fertilizer would act as a core for soil aggregation which contributed to formation of macro-aggregate according to the aggregate formation model (TIisdall \& Oades, 1982). What's more, the organic matter would also provide nutrients to soil microbes, and promote soil microbial activity and enzyme activity. Soil aggregate stability increased with microbial development, and that hypha development outside the rhizosphere, particularly by mycorrhizal fungus, provided nutrients to microorganisms, which enhanced the development of microorganisms and increased the soil aggregate stability in turn (Zhang, Liu, Chen, \& Tang, 2016). Consequently, the application of organic materials would favor the aggregation of clay and micro-aggregate, which caused a decrease in clay and micro-aggregate fractions and an increase in macro-aggregate.

However, the effects of bio-fertilizer supplemented with $30 \%$ or $70 \%$ chemical fertilizer were not much effective in both years. The result obtained may have been due to the threshold effect of bio-fertilizer application, the inadequate dose of bio-fertilizer application would not be benefit for the soil aggregation. Promotion of bacterial and fungal activity increased with the amount of bio-fertilizer when it was less than $50 \%$, then the promotion would generally diminish when the amount of bio-fertilizer was higher than $50 \%$. The higher proportion of macro-aggregate and MWD values in treatments with bio-fertilizer accord with previous study and proved our hypotheses that bio-fertilizer are able to improve soil aggregation and the promotion of biofertilizer may be related to its dose in the given area. In our study, the bio-fertilizer applied alone showed no positive effect on soil macro-aggregate content and water stable aggregate stability. The inappropriate 
application of bio-fertilizer would not achieve expected result.

Different from the effect on macro-aggregate, bio-fertilizer generally had a negative effect on the microaggregate. The orders of micro-aggregate were as follows: $\mathrm{BF} 0=\mathrm{BF} 30>\mathrm{BF} 70=\mathrm{BF} 100>\mathrm{BF} 50$. The maximum negative on the content of micro-aggregate was achieved with BF50. Our results showed that the micro-aggregate was more stable than the macro-aggregate since the variation of micro-aggregate was $4.5 \mathrm{~g}$

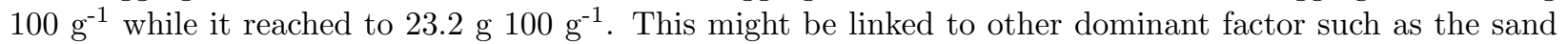
and silt content of soil (high sand content of soil which was above $70 \%$ in this study soil) that played a vital role in the soil aggregation. Generally, combined with bio-fertilizer application would lead to increased soil aggregate stability than applied chemical fertilizer or bio-fertilizer alone. Previous study showed that fungal based bio-fertilizer contributed more to macro-aggregate, while the bacterial based bio-fertilizer linked more to micro-aggregate (Hernandez-Soriano, Kerre, Kopittke, Horemans, \& Smolders, 2016; Yilmaz \& Sonmez, 2017).

\subsection{Soil and aggregate organic $\mathrm{C}$ fractions}

Our results showed that the increase of SOC, MBC, WSOC and $\mathrm{KMnO}_{4}$-C were associated with the application of bio-fertilizer. Similarly, Li et al. (2017) indicated that concentrations of SOC and WSOC were significantly higher in treatments mixed with bio-fertilizer when compared with soil applied with chemical fertilizer alone. In our study, the application of bio-fertilizer significantly increased SOC in the whole soil in both years, and the whole-soil SOC concentrations increased with the increasing bio-fertilizer. The increases were mainly attributed to input of newly organic matter through bio-fertilizer. What's more, the increase of nutrient supply by the addition of bio-fertilizer led to increase crop residues return to soil, which increased the SOC content in turn. The input of bio-fertilizer could provide substrate for soil microbes on one hand and bring amounts of microorganisms on the other hand (Banger, Toor, Biswas, Sidhu, \& Sudhir, 2010). As one of the labile fractions of C, WSOC appears to be an immediate substrate for the soil organisms. WSOC was significantly increased after bio-fertilizer application, and the highest WSOC was recorded in BF50. The increase of WSOC might be due to the priming effect of supply of organic material through bio-fertilizer application, which spurred the mineralization of organic matter via increasing microbial activity. Similarly, the $\mathrm{KMnO}_{4}$-C was significantly higher in treatment applied with bio-fertilizer, while the basal respiration was generally decreased by bio-fertilizer. In addition, the significant relationship (positive or negative) between organic $\mathrm{C}$ fractions also suggested that bio-fertilizer application was benefit for soil $\mathrm{C}$ sequestration.

The relationship between the organic $\mathrm{C}$ fractions and proportions of macro-aggregate were positively significant except for basal respiration in this study. This correlation confirmed that increases in soil labile organic C content would promote the soil aggregate stability, which was mainly dominated by the proportions of macro-aggregate (Bronick \& Lal, 2005; Sui, Jiao, Liu, Zhang, \& Ding, 2012). Previous studies also indicated increased SOC or soil organic matter would cause an increase in soil aggregate stability (Chenu, Le Bissonnais, \& Arrouays, 2000; Huang, Lan, Liu, \& Gao, 2017).

Generally, the stabilization of organic $\mathrm{C}$ in soil aggregates is considered one of the main mechanisms for sequestering $\mathrm{C}$ in soil. The organic $\mathrm{C}$ in soil aggregates can be protected it from soil microorganisms and soil enzymes, which reduced the decomposition of SOC. The soil applied with bio-fertilizer had larger organic $\mathrm{C}$ concentrations in the three aggregate fractions than the control in both years, and the highest increase in the organic $\mathrm{C}$ was recorded in the BF50 treatment. Previous studies showed that application of fungal based fertilizer or fungus was also effective in increasing organic $\mathrm{C}$ of aggregates (Hu, Cui, Dai, Wang, \& Lin, 2014; Yilmaz \& Sonmez, 2017). The increase in organic C content of aggregates caused by bio-fertilizer application might be linked to that the bio-fertilizer provided the suitable environment with new and easily degradable $\mathrm{C}$ for the soil microbes. The organic matter of bio-fertilizer used in this study accounted for $55 \%$ of the total weight and significant increases of organic $\mathrm{C}$ in whole soil was recorded with the supplement of bio-fertilizer.

In this study, the SOC was distributed among the three aggregate fractions, and the organic $\mathrm{C}$ in each aggregate fraction partly linked to concentrations of the whole soil organic C. However, the difference of the 
proportion among aggregate fractions was not consistent with the distribution of each aggregate. This might indicate that the bio-fertilizer would first influence the physical properties and affect soil chemical properties thereafter. Soil treated with bio-fertilizer (organic materials) showed relative high organic $\mathrm{C}$ content in micro-aggregate than the control, which was consistent with results of Hernandez-Soriano et al. (2016). These results were very meaningful from the perspective of soil $\mathrm{C}$ sequestration because it was believed that organic $\mathrm{C}$ was predominantly fixed in micro-aggregates. The organic $\mathrm{C}$ in micro-aggregates was more stable and remained unaltered for a relative long time in soil (Huang et al., 2019). However, the dynamics of macro-aggregate were also vital to $\mathrm{C}$ fixation for the reason that micro-aggregate formation and the organic $\mathrm{C}$ fixed within the micro-aggregates were affected by macro-aggregate (Six et al., 2000).

\section{Conclusions}

The soil labile organic $\mathrm{C}$ fractions, except for basal respiration, were generally increased after bio-fertilizer application, which was helpful to $\mathrm{C}$ fixation in soil. The proportions of macro-aggregate and aggregate stability assessed by mean weight diameter were also significantly improved by bio-fertilizer. This research showed that bio-fertilizer supplement had significant positive effects on soil C sequestration and soil aggregate stability. It was recorded that the supplement of $50 \%$ bio-fertilizer combined with chemical fertilizer was more effective. Considering the increases of soil $\mathrm{C}$ and aggregate stability, it was believed that bio-fertilizer made markedly contributions to soil physical and chemical properties.

Therefore, we concluded that $50 \%$ bio-fertilizer supplemented chemical fertilizer could effectively improve soil C fixation and soil aggregate stability in a sustainable way. This study, however, was a snapshot record only after two year's bio-fertilizer application. Thus, long-term experiment was required to complete assess the effects of bio-fertilizer application.

Acknowledgements This research was financially supported by the National Key Research and Development Program of China (2018YFD0300704), Foundation of He'nan Educational Committee (20B210025), and the School-based Project of Zhoukou Normal University (ZKNUC2018012).

\section{References:}

Bado, B. V., Lompo, F., Sedogo, M. P., \& Cescas, M. P. (2010). Establishment of the critical limit of soil-available phosphorous for maize production in low acidic ultisols of west Africa. Communications in Soil Science 83 Plant Analysis, 41 (8), 968-976. doi: 10.1080/00103621003646055

Banger, K., Toor, G. S., Biswas, A., Sidhu, S. S., \& Sudhir, K. (2010). Soil organic carbon fractions after 16-years of applications of fertilizers and organic manure in a Typic Rhodalfs in semi-arid tropics. Nutrient Cycling in Agroecosystems, 86 (3), 391-399. doi: 10.1007/s10705-009-9301-8

Bethlenfalvay, G. J., \& Barea, J. M. (1994). Mycorrhizae in sustainable agriculture. I. Effects on seed yield and soil aggregation. American Journal of Alternative Agriculture, 9 (04), 157-161. doi: $10.1017 /$ S0889189300005919

Blair, G. J., Lefroy, R., \& Lisle, L. (1995). Soil carbon fractions based on their degree of oxidation, and the development of a carbon management index for agricultural systems. Australian Journal of Agricultural Research, 46 (7), 393-406. doi: 10.1071/AR9951459

Bronick, C. J., \& Lal, R. (2005). Manuring and rotation effects on soil organic carbon concentration for different aggregate size fractions on two soils in northeastern Ohio, USA. Soil and Tillage Research, 81 , 239-252. doi: 10.1016/j.still.2004.09.011

Bronick, C. J., \& Lal, R. (2005). Soil structure and management: a review. Geoderma, 124 (1-2), 3-22. doi: 10.1016/j.geoderma.2004.03.005

Carter, M. R., Kunelius, H. T., \& Angers, D. A. (1994). Soil structural form and stability, and organic matter under cool-season perennial grasses. Soil Science Society of America Journal, 58 (4), 1194-1199. doi: $10.2136 /$ sssaj1994.03615995005800040027x 
Chenu, C., Le Bissonnais, Y., \& Arrouays, D. (2000). Organic matter influence on clay wettability and soil aggregate stability. Soil Science Society of America Journal, 64 (4), 1479. doi: 10.2136/sssaj2000.6441479x

Cui, Z., Zhang, H., Chen, X., Zhang, C., Ma, W., Huang, C., . . . Dou, Z. (2018). Pursuing sustainable productivity with millions of smallholder farmers. Nature, 555 (7696), 363-366. doi: 10.1038/nature25785

Elliott, E. T. (1986). Aggregate structure and carbon, nitrogen, and phosphorus in native and cultivated soils. Soil Science Society of America Journal, 50 (3), 627-633. doi: 10.2136/sssaj1986.03615995005000030017x

Gong, W., Yan, X., \& Wang, J. (2012). The effect of chemical fertilizer on soil organic carbon renewal and $\mathrm{CO}_{2}$ emission - a pot experiment with maize.Plant $\mathcal{E}$ Soil, 353 (1-2), 85-94. doi: 10.1007/s11104-011-1011-8

Graf, F., \& Frei, M. (2013). Soil aggregation and slope stability related to soil density, root length, and mycorrhiza. Egu General Assembly Conference EGU General Assembly Conference Abstracts

Hernandez-Soriano, M. C., Kerre, B., Kopittke, P. M., Horemans, B., \& Smolders, E. (2016). Biochar affects carbon composition and stability in soil: a combined spectroscopy-microscopy study. Scientific Reports, 6 , 25127. doi: $10.1038 /$ srep25127

Hu, J., Cui, X., Dai, J., Wang, J., \& Lin, X. (2014). Interactive effects of Arbuscular Mycorrhizaeand maize (Zea mays L.) straws on wheat (Triticum aestivumL.) growth and organic carbon storage in a sandy loam soil. Soil \& Water Research, 9 (3), 119-126. doi: 10.17221/77/2013-SWR

Huang, R., Lan, M., Liu, J., \& Gao, M. (2017). Soil aggregate and organic carbon distribution at dry land soil and paddy soil: the role of different straws returning. Environmental Science 83 Pollution Research, 24 (36), 1-11. doi: 10.1007/s11356-017-0372-9

Huang, X., Jia, Z., Guo, J., Li, T., Sun, D., Meng, H., . . . Shen, Q. (2019). Ten-year long-term organic fertilization enhances carbon sequestration and calcium-mediated stabilization of aggregate-associated organic carbon in a reclaimed Cambisol. Geoderma, 355 , 113880. doi: 10.1016/j.geoderma.2019.113880

Jones, D. L., \& Willett, V. B. (2006). Experimental evaluation of methods to quantify dissolved organic nitrogen (DON) and dissolved organic carbon (DOC) in soil. Soil Biology 83 Biochemistry, 38 (5), 991-999. doi: $10.1016 /$ j.soilbio.2005.08.012

Kumar, U., Shahid, M., Tripathi, R., Mohanty, S., \& Nayak, A. K. (2017). Variation of functional diversity of soil microbial community insub-humid tropical rice-rice cropping system under long-termorganic and inorganic fertilization.Ecological Indicators, 1 (73), 536-543. doi: 10.1016/j.ecolind.2016.10.014

Lal, R. (2009). Sequestering carbon in soils of arid ecosystems. Land Degradation \&3 Development, 20 (4), 441-454. doi: 10.1002/ldr.934

Li, R., Tao, R., Ling, N., \& Chu, G. (2017). Chemical, organic and bio-fertilizer management practices effect on soil physicochemical property and antagonistic bacteria abundance of a cotton field: Implications for soil biological quality. Soil \&3 Tillage Research, 167 , 30-38. doi: 10.1016/j.still.2016.11.001

Liang, B. C., Mackenzie, A. F., Schnitzer, M., Monreal, C. M., Voroney, P. R., \& Beyaert, R. P. (1997). Management-induced change in labile soil organic matter under continuous corn in eastern Canadian soils. Biology \& Fertility of Soils, 26 (2), 88-94. doi: 10.1007/s003740050348

Liang, L. Z., Zhao, X. Q., Yi, X. Y., Chen, Z. C., Dong, X. Y., Chen, R. F., \& Shen, R. F. (2013). Excessive application of nitrogen and phosphorus fertilizers induces soil acidification and phosphorus enrichment during vegetable production in Yangtze River Delta, China. Soil Use 63 Management, 29 (2), 161-168. doi: 10.1111/sum. 12035

Liu, S., Razavi, B. S., Su, X., Maharjan, M., Zarebanadkouki, M., Blagodatskaya, E., \& Kuzyakov, Y. (2017). Spatio-temporal patterns of enzyme activities after manure application reflect mechanisms of niche differentiation between plants and microorganisms. Soil Biology and Biochemistry, 112 , 100-109. doi: 10.1016/j.soilbio.2017.05.006 
Ramesh, T., Bolan, N. S., Kirkham, M. B., Wijesekara, H., Kanchikerimath, M., Srinivasa Rao, C., . . - Freeman Ii, O. W. (2019). Soil organic carbon dynamics: Impact of land use changes and management practices: A review. Advances in Agronomy,156, 1-107. doi: 10.1016/bs.agron.2019.02.001

Singh, S., Tripathi, A., Maji, D., Awasthi, A., Vajpayee, P., \& Kalra, A. (2019). Evaluating the potential of combined inoculation of Trichoderma harzianum andBrevibacterium halotolerans for increased growth and oil yield in Mentha arvensis under greenhouse and field conditions. Industrial Crops and Products, 131, 173-181. doi: $10.1016 /$ j.indcrop.2019.01.039

Su, Y. Z., Wang, F., Suo, D. R., Zhang, Z. H., \& Du, M. W. (2006). Long-term effect of fertilizer and manure application on soil-carbon sequestration and soil fertility under the wheat-wheat-maize cropping system in northwest China.Nutrient Cycling in Agroecosystems, 75 (1-3), 285-295. doi: 10.1007/s10705-006-9034-x

Sui, Y. Y., Jiao, X. G., Liu, X. B., Zhang, X. Y., \& Ding, G. W. (2012). Water-stable aggregates and their organic carbon distribution after five years of chemical fertilizer and manure treatments on eroded farmland of Chinese Mollisols.Canadian Journal of Soil Science, 92 (3), 551-557. doi: 10.4141/cjss2010-005

Tang, H., Xiao, X., Li, C., Wang, K., \& Pan, X. (2018). Impact of long-term fertilization practices on the soil aggregation and humic substances under double-cropped rice fields.Environmental Science $\&$ P Pollution Research, 25 (4), 11034-11044. doi: 10.1007/s11356-018-1365-z

TIisdall, J. M., \& Oades, J. M. (1982). Organic matter and water-stable aggregates in soils. Journal of Soil Science, 32, 141-163. doi: 10.1111/j.1365-2389.1982.tb01755.x

Tripathi, R., Nayak, A. K., Bhattacharyya, P., Shukla, A. K., \& K., T. V. (2014). Soil aggregation and distribution of carbon and nitrogen in different fractions after 41 years long-term fertilizer experiment in tropical rice-rice system.Geoderma, 213 , 280-286. doi: 10.1016/j.geoderma.2013.08.031

Vessey, J. K. (2003). Plant growth promoting rhizobacteria as biofertilizers. Plant \&5 Soil, 255 (2), 571-586. doi: $10.1023 / \mathrm{a}: 1026037216893$

Wu, J., Joergensen, R. G., Pommerening, B., Chaussod, R., \& Brookes, P. C. (1990). Measurement of soil microbial biomass C by fumigation-extraction - an automated procedure. Soil Biology $E_{3}$ Biochemistry, 22 (8), 1167-1169. doi: 10.1016/0038-0717(90)90046-3

Wu, L., Chen, J., Wu, H., Qin, X., Wang, J., Wu, Y., . . . Luo, X. (2016). Insights into the regulation of rhizosphere bacterial communities by application of bio-organic fertilizer in Pseudostellaria heterophylla monoculture regime.Frontiers in Microbiology, 7 , 1788. doi: 10.3389/fmicb.2016.01788

Yilmaz, E., \& Sonmez, M. (2017). The role of organic/bio-fertilizer amendment on aggregate stability and organic carbon content in different aggregate scales. Soil 6 Tillage Research, 168 , 118-124. doi: 10.1016/j.still.2017.01.003

Zhang, F., Xu, X., Wang, G., Wu, B., \& Xiao, Y. (2020). Medicago sativa and soil microbiome responses to Trichoderma as a biofertilizer in alkaline-saline soils.Applied Soil Ecology, 153 , 103573. doi: 10.1016/j.apsoil.2020.103573

Zhang, H., Ding, W., Yu, H., \& He, X. (2015). Linking organic carbon accumulation to microbial community dynamics in a sandy loam soil: result of 20 years compost and inorganic fertilizers repeated application experiment. Biology \& Fertility of Soils, 51 (2), 137-150. doi: 10.1007/s00374-014-0957-0

Zhang, H., Liu, Z., Chen, H., \& Tang, M. (2016). Symbiosis of Arbuscular Mycorrhizal fungi andRobinia pseudoacacia L. improves root tensile strength and soil aggregate stability. Plos One, 11 (4), e0153378. doi: 10.1371/journal.pone.0153378

Zhang, P., Wei, T., Jia, Z., Han, Q., Ren, X., \& Li, Y. (2014). Effects of straw incorporation on soil organic matter and soil water-stable aggregates content in semiarid regions of northwest China. Plos One, 9 (3), e92839. doi: 10.1371/journal.pone.0092839 
Zhang, S., Huang, S., Li, J., Guo, D., Lin, S., \& Lu, G. (2017). Long-term manure amendments and chemical fertilizers enhanced soil organic carbon sequestration in a wheat (Triticum aestivum L.)-maize (Zea mays L.) rotation system. Journal of the Science of Food $\& 3$ Agriculture, 97 , pags. 2575-2581. doi: 10.1002/jsfa.807

\section{Hosted file}

Tables.docx available at https://authorea.com/users/324131/articles/452427-promoted-soil-cand-aggregate-stability-in-soil-applied-with-bio-fertilizer-in-north-china-plain
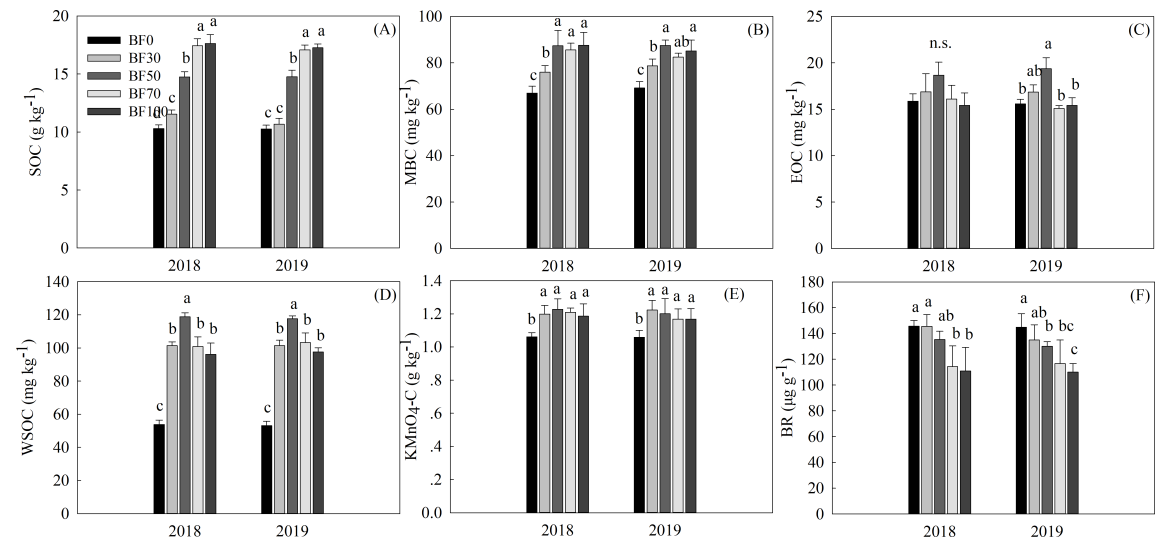